\title{
Sheep embryos derived from FSH/eCG treatment have a lower in vitro viability after vitrification than those derived from FSH treatment
}

\author{
Giovanni LeOni*, Luisa Bogliolo, Pierpaolo Pintus, \\ Sergio LEDDA, Salvatore NAITANA
}

Department of Animal Biology, University of Sassari, 07100 Sassari, Italy

(Received 20 February 2001; accepted 7 May 2001)

\begin{abstract}
In the non breeding period, the effect of two superovulatory treatments (eCG/FSH in single dose or FSH alone in four decreasing doses) on the production of embryo quality following in vitro viability after vitrification procedures was investigated using forty-four adult Sarda breed ewes. In sheep treated with eCG/FSH, the mean number of corpora lutea was significantly $(P<0.05)$ higher $(11.8 \pm 4.0$ vs. $8.05 \pm 3.8)$, although the recovery rate was significantly $(P<0.01)$ lower $(74.6$ vs. 59.9$)$ than with FSH alone. After vitrification (ethylene glycol and glycerol) was repeated three times, the rates of re-expansion at first and second warming were significantly $(P<0.01)$ higher in embryos derived from FSH alone than in those with both gonadotrophins (94.9 and 41.9 vs. 72.8 and 18.6) and after the last vitrification the hatched blastocyst rates were 22.5 and 7.6. After differential stain, blastocysts derived from FSH alone showed a mean number of cells significantly higher than blastocysts from eCG/FSH (184.2 vs. 157.7). It was concluded that superovulatory treatment with eCG/FSH may increase the ovarian responses compared with FSH alone, but these embryos showed a reduction in viability rates after repeated vitrification.
\end{abstract}

superovulation / embryo quality / ovine / vitrification / viability

Résumé - Les embryons ovins obtenus après un traitement de superovulation associant FSH et eCG ont une viabilité in vitro plus faible après vitrification que les embryons obtenus avec un traitement séquentiel de FSH. Pendant la saison non reproductive, on a évalué, chez 44 brebis adultes de race Sarde, l'effet de deux traitements de superovulation (le premier avec les eCG/FSH en une seule administration, le deuxième avec la FSH administrée en quatre doses décroissantes) sur la qualité des embryons produits et sur la viabilité in vitro après vitrification. Dans le groupe traité avec les eCG/FSH, le nombre moyen d'ovulations était plus élevé $(11,8 \pm 4,0$ vs. $8,05 \pm 3,8, P<0,05)$ tandis que le taux de récupération était plus faible (74,6 vs. 59,9, $P<0,01)$ par rapport au groupe traité avec la FSH seule. Les embryons ont suivi 3 vitrifications successives (éthylène glycol et glycérol).

* Correspondence and reprints

E-mail: vetfis@ssmain.uniss.it 
Les pourcentages de réexpansion de la cavité blastocoelique après les deux premiers cycles de vitrification-décongélation étaient significativement $(P<0,01)$ supérieurs pour les embryons dérivés du traitement avec la FSH seule par rapport à ceux dérivés du traitement effectué avec les deux gonadotropines $(94,9$ et 41,9 vs. 72,8 et 18,6$)$. Après la dernière vitrification, les pourcentages d'éclosion étaient respectivement de 22,5 et de 7,6 pour les groupes FSH et eCG/FSH. Après coloration différentielle, les blastocystes dérivés du traitement avec la FSH seule avaient un nombre moyen de cellules supérieur $(P<0,01)$ par rapport aux blastocystes dérivés du traitement avec eCG/FSH $(184,2$ vs. 157,7). En conclusion, le traitement superovulatoire avec eCG/FSH augmente la réponse ovarienne par rapport au traitement avec la FSH seule, mais ces embryons montrent une réduction des taux de survie en culture après les processus répétés de vitrification-décongélation.

superovulation / qualité embryonnaire / ovin / vitrification / vitalité

\section{INTRODUCTION}

Although significant progress has been made in assisted reproductive technology, during the last two decades multiple ovulations by gonadotrophin treatments still represents the greater source of embryos for all technologies connected to embryo transfer programs in domestic species [15].

Experiences have been reported extensively in the literature regarding multiple ovulation in sheep, but, superovulatory treatment is still not a well-controlled practice [for review see 6,20 ]. The success of embryo transfer depends on several factors including the mating system, flushing procedure, progesterone dose and donor ewe age [4], donor breed [35] and age [27], seasonal treatment [34], gonadotrophin derived species preparation [5], gonadotrophins dissolving agent [11]. However, a high degree of variation in the superovulatory response continues to be the greatest problem limiting application of the embryo transfer program in field conditions [40]. Potential factors such as follicular dominance [28] and ovarian status [21], can have a great influence on ovarian responses. However, none of these explain sufficiently the cause of variability in ovarian superovulatory responses since not little is known about genetic control of ovarian dynamic mechanisms.

The combination of multiple ovulations with cryopreservation can overcome this problem in particular when the number of recipients is insufficient for transfer of all recovered embryos. Cryopreservation is an integral part of embryo transfer programs and shows several advantages such as lower cost of long distance transport, decreased risk of disease transmission, and has the added advantage of allowing imported stocks to develop in recipients well adapted to local conditions. Two methods are available for ovine embryo cryopreservation which permit the birth of lambs following transfer of frozen-thawed $[32,41]$ or vitrified-warmed embryos [1, 25]. Direct transfer of vitrified sheep embryos [23] can have a major role in the development of breeding programs and an important impact on the prosperity of economically underdeveloped regions. However, when cryopreservation technology is used, embryo quality must be extremely good to overcome embryo susceptibility to low temperatures and maintain a high potential viability rate. Authors [19, 38] evidenced that embryos can survive to multiple cycles of freezing and this could introduce new applications of reproductive technologies as genetic analysis of thawed, biopsied and refrozen embryos [13].

Vitale et al. [38] evidenced a cumulative negative effect on in vitro viability after threerepetitive freezing of mouse $8-16$ cell embryos, with a constant amount of damage at each cycle. Therefore, cryopreservation 
could be considered as a selecting agent of more viable embryos [22].

An other limiting aspect in embryo transfer programs is the collection of an inadequate number of good quality embryos from donors. The ratio of FSH to $\mathrm{LH}$ in the gonadotrophin preparations $[8,10]$ affect the quality of embryos recovered from superovulated sheep. FSH is a superior gonadotrophin to eCG in sheep and goats $[3,14]$ probably due to the high LH bioactivity of eCG. Both the variability in the ovarian response and the quality of embryo yield are the main limiting factors in small ruminant transfer programs.

The current study was undertaken to assess, firstly, the potential production of good quality embryos by administering either in a single injection a combination of $\mathrm{FSH}$ and eCG or giving repeated injections of FSH, and, secondly, to compare their in vitro potential viability after cryopreservation repeated three times using a vitrification procedures.

\section{MATERIALS AND METHODS}

During the non breeding period (AprilMay), in four replicate experiments, 44 adult Sarda ewes, between 2 and 6 years of age, were kept inside for the duration of the experiments and were fed a liveweight maintenance ration.

\subsection{Embryos production}

The animals were synchronized by intravaginal sponges (Chronogest, Intervet, Booxmer, Netherlands) impregnated with $40 \mathrm{mg}$ of fluorogestone acetate (FGA) and inserted for 12 days. $24 \mathrm{~h}$ before sponge removal, 21 ewes received 250 IU FSH-p (Pluset, Serono, Rome, Italy) diluted in $16 \mathrm{ml}$ of saline solution in 4 decreasing doses over $2 \mathrm{~d}$ (94 to $78 ; 47$ to $31 \mathrm{IU})$ at $12 \mathrm{~h}$ intervals and 23 ewes received a single injection of 125 IU FSH-p and 600 IU eCG
(Intervet, Booxmer, Netherlands). At 50 hours after sponge removal, the ewes were inseminated with fresh diluted semen $\left(80 \times 10^{6}\right.$ spermatozoa) using the laparoscopic technique. Five days after the insemination (day 6 after estrus) uterine horns were flushed from the donors via mid-ventral laparotomy under general anesthesia induced and maintained by thiopentale sodium (Pentothal sodium, Gellini, Aprilia, Italy) and ovarian responses, ova and embryos were recorded. Each uterine horn was flushed with Dulbecco's phosphate buffer (PBS, Sigma Chemical Co., St. Louis, MO, USA) supplemented with $5 \mathrm{mg} \cdot \mathrm{mL}^{-1}$ bovine serum albumin (Fraction V, Sigma) and antibiotics (penicillin and streptomycin).

After washing in fresh flushing medium, all ova and embryos were examined under an inverted microscope at magnification of 20-40 × (Leitz Labovert, Wetzlar, Germany) and classified according to their stage of development and morphology [33].

\subsection{Differential staining}

Blastocysts derived from FSH alone $(n=13)$ and eCG/FSH $(n=15)$, randomly withdrawn, were differentially labeled with specific fluochrome to count the trophectoderm (TE) and inner cell mass (ICM) nuclei [37]. Briefly, embryos were incubated in $10 \mathrm{mM}$ trinitrobenzene-sulphonic acid (TNBS; Sigma) in PBS containing $3 \mathrm{mg} \cdot \mathrm{mL}^{-1}$ polyvinylpyrrolidone (PVP-40; Sigma) for 10 min TNBS combines with $\mathrm{N}$-terminal amines and labels thus phopholipids or proteins, which are present in the cell membrane. After washing in TCM-199 Hepes, embryos were incubated in a 30:70 dilution of rabbit anti-DNP-BSA (Sigma) in TCM199 bicarbonate for $30 \mathrm{~min}$.

After a quick wash in TCM199 Hepes, the embryos were incubated in a 1:4 dilution of guinea pig complement (Sigma) in TCM199-bicarbonate supplemented with $10 \mu \mathrm{g} \cdot \mathrm{mL}^{-1}$ propidium iodide (PI; Sigma) for $30 \mathrm{~min}$ at $39{ }^{\circ} \mathrm{C}$. Cells which were 
labeled with the antiserum were lysed when the complement was added. After finishing the complement mediated cell lysis and the staining of the lysed cells by propidium iodide, embryos were briefly washed in icecold TCM199 Hepes, supplemented with $10 \mu \mathrm{g} \cdot \mathrm{mL}^{-1}$ propidium iodide. After 3-5 min of fixation, the embryos were transferred for 3-5 $\min$ to $10 \mu \mathrm{g} \cdot \mathrm{mL}^{-1}$ bisbenzimide (Hoechst 33342; Sigma) in absolute alcohol at room temperature. Then the embryos were transferred to a drop of glycerol on a microscopic slide and covered with a coverslip. Embryos were examined under fluorescence microscope (Diaphot, Nikon, Tokyo, Japan).

Thus a number ICM nuclei, which appeared blue, and TE nuclei, which appeared pink to red, were counted and the proportion of ICM-cells to the total cell number of individual embryos was evaluated under the microscope.

\subsection{Vitrification and warming procedures}

Immediately after recovery blastocysts were vitrified according to Naitana et al. [26]. Briefly, vitrification and warming solution were prepared using PBS, antibiotics supplemented with $0.1 \%$ PVA. Embryos were put into $200 \mu \mathrm{L}$ drops of $1.4 \mathrm{M}$ glycerol for $5 \mathrm{~min}$, then into $200 \mu \mathrm{L}$ drops of 1.4 M glycerol and 3.6 M ethylene glycol for $5 \mathrm{~min}$ before being transferred into a $20 \mu \mathrm{L}$ column of $3.4 \mathrm{M}$ glycerol and $4.6 \mathrm{M}$ ethylene glycol, and loaded into the center of $0.25 \mathrm{~mL}$ straws using a fine glass capillary pipette. In the straws, the embryos and vitrification solution were separated by 4 air bubbles $(60 \mu \mathrm{L})$ from 2 columns $(160 \mu \mathrm{L})$ of $0.5 \mathrm{M}$ sucrose solution. After sealing the straws were immediately plunged into LN2 and kept in it.

For warming, the straws were transferred from LN2 into a water bath at $35{ }^{\circ} \mathrm{C}$ for $10 \mathrm{~s}$. The content of each straw was expelled into Petri dishes (Falcon) and stirred gently to facilitate the mixture of both solutions. The embryos were retrieved and transferred into $200 \mu \mathrm{L}$ drops of $0.25 \mathrm{M}$ sucrose solution for $3 \mathrm{~min}$ to allow for the removal of intracellular cryoprotectants. The embryos, after washing, were transferred into $500 \mu \mathrm{L}$ TCM199 with $10 \%$ FCS in four well tissue culture dishes (NUNC, Denmark) at $5 \% \mathrm{CO}_{2}$ in air, $39^{\circ} \mathrm{C}$ and $100 \%$ humidity and examined at $12 \mathrm{~h}$ intervals. The embryos that re-expanded and redeveloped the blastocoelic cavity were considered to be viable. These embryos were cryopreserved for a second time using the same vitrification, warming and culture procedures as above. Viable embryos were cryopreserved for a third time by the same procedures.

\subsection{Statistical analysis}

The analysis of variance test (Anova) or Chi-square were used to determine the differences between ovarian responses, recovery rates and number of embryonic cells, and in vitro viability rates after vitrification and warming procedures. Probability values of less than 0.05 were considered significant.

\section{RESULTS}

The time of onset of estrus after sponge removal was similar ( $28.6 \pm 4.2$ vs. $27.3 \pm$ 4.9 ; mean \pm SD) for both superovulatory treatments. The ovarian responses (range 3 to 19 of corpora lutea) per sheep reflected the expected pattern of a large variation between individuals receiving the two treatments. The mean number of corpora lutea was significantly lower $(P<0.05)$ in sheep treated with FSH alone than with eCG/FSH $(8.05 \pm 3.8$ vs. $11.8 \pm 4.0)$ while the recovery rate was significantly $(P<0.01)$ higher (74.6 vs. 59.9). No differences were found in fertilization rates and blastocyst yeld between the two treatments (Tab. I). Differential staining showed that (Tab. II) the mean number of trophoblastic cells and inner 
Table I. Superovulatory responses, recovery, fertilization and embryo production after treatment with FSH or eCG/FSH in Sarda sheep.

\begin{tabular}{|c|c|c|c|c|c|c|c|}
\hline \multirow[t]{2}{*}{ Treatment } & \multirow{2}{*}{$\begin{array}{l}\text { Number } \\
\text { of sheep }\end{array}$} & \multirow{2}{*}{$\begin{array}{c}\text { Number of } \\
\text { corpora lutea } \\
(\text { mean } \pm \text { SD) }\end{array}$} & \multirow{2}{*}{$\begin{array}{c}\text { Recovery } \\
(\%)\end{array}$} & \multirow{2}{*}{$\begin{array}{l}\text { Fertilization } \\
\qquad(\%)\end{array}$} & \multicolumn{3}{|c|}{ Percentage of } \\
\hline & & & & & degenerated & morula & blastocysts \\
\hline FSH & 21 & $8.05 \pm 3.8^{\mathrm{a}}$ & $\begin{array}{c}126 \\
(74.6)^{\mathrm{c}}\end{array}$ & $\begin{array}{c}103 \\
(81.7)\end{array}$ & 3.9 & 7.8 & 88.3 \\
\hline eCG/FSH & 23 & $11.8 \pm 4.0^{\mathrm{b}}$ & $\begin{array}{c}178 \\
(59.9)^{\mathrm{d}}\end{array}$ & $\begin{array}{c}146 \\
(82.0)\end{array}$ & 6.9 & 12.3 & 80.8 \\
\hline
\end{tabular}

Different superscripts are statistically different: ${ }^{\mathrm{a}}$ vs. ${ }^{\mathrm{b}}=P<0.05 ;{ }^{\mathrm{c}}$ vs. ${ }^{\mathrm{d}}=P<0.01$.

Table II. Count of number cells of blastocysts after differential staining.

\begin{tabular}{lcccc}
\hline $\begin{array}{l}\text { Derived } \\
\text { embryos }\end{array}$ & $\begin{array}{c}\text { Stained } \\
\text { embryos }\end{array}$ & $\begin{array}{c}\text { Total cells } \\
(\text { mean } \pm \text { SD })\end{array}$ & $\begin{array}{c}\text { Inner cell mass } \\
(\text { mean } \pm \text { SD })\end{array}$ & $\begin{array}{c}\text { Ratio } \\
\text { ICM/tot }(\%)\end{array}$ \\
\hline FSH & 13 & $184.2 \pm 31^{\mathrm{a}}$ & $66 \pm 3.8^{\mathrm{a}}$ & 35.8 \\
eCG/FSH & 15 & $157.7 \pm 25^{\mathrm{b}}$ & $50 \pm 3.1^{\mathrm{b}}$ & 31.8 \\
\hline
\end{tabular}

Different superscripts are statistically different: ${ }^{\mathrm{a}} \mathrm{vs}{ }^{\mathrm{b}}=P<0.05$.

cell mass cells was significantly $(P<0.01)$ higher in embryos derived from FSH alone than in those from eCG/FSH (184.2 \pm 31 vs. $157.7 \pm 25$ and $66 \pm 3.8$ vs. $50 \pm 3.1)$.

Based on a subjective visual assessment of embryo quality related only to the stage of development, there was no observable difference in embryo quality between the two superovulatory treatments. The viability rates of vitrified embryos in the in vitro system is given in Table III. After repeated vitrification, the rates of re-expansion at first and second warming were significantly $(P<0.01)$ higher in embryos derived from FSH alone than in those with both gonadotrophins (94.9 and 41.9 vs. 72.8 and 18.6) and after the last vitrification the hatched blastocysts rates were 22.5 and 7.6 (Tab. III).

Table III. In vitro viability of blastocysts derived from two superovulatory treatments after repeated 3 times vitrification and warming procedures.

\begin{tabular}{lcccc}
\hline & & \multicolumn{3}{c}{ Repeated vitrification } \\
\cline { 3 - 5 } Treatments & $\begin{array}{c}\text { Number } \\
\text { of embryos }\end{array}$ & \multicolumn{2}{c}{$\begin{array}{c}\text { 2nd } \\
\text { Re-expansion } \\
\text { after 12 h (\%) }\end{array}$} & $\begin{array}{c}\text { 3rd } \\
\text { Hatched } \\
\text { embryos }(\%)\end{array}$ \\
\hline FSH & 78 & $74(94.9)^{\mathrm{a}}$ & $31(41.9)^{\mathrm{a}}$ & $7(22.5)^{\mathrm{a}}$ \\
FSH/eCG & 103 & $75(72.8)^{\mathrm{b}}$ & $13(17.3)^{\mathrm{b}}$ & $1(7.6)^{\mathrm{b}}$ \\
\hline
\end{tabular}

Different superscripts are statistically different: ${ }^{\mathrm{a}}$ vs. ${ }^{\mathrm{b}}=P<0.01$. 


\section{DISCUSSION}

Our data confirm the results of other studies with Merino ewes showing that FSH/eCG increases the ovarian response $[17,29]$ but the embryos obtained showed higher sensitivity to low temperatures than those from FSH alone. Although some evidence has been observed of an alteration in oocyte activation and in patterns of oocyte protein synthesis, or follicular steroidogenesis capacity [24] and ovulation time [39], the reason why FSH alone produces better quality embryos than eCG is not fully understood. Armstrong [2] has suggested that acceleration of follicle development during superovulatory treatment can occur before complete growth to allow completion of maturational process of cytoplasmic oocyte and granulosa cells. Driancourt and Fry [12] have shown that eCG could determine variations in the morphological features of the preovulatory follicles, altering the size and number of granulosa cells which play an essential role in the transport of regulatory signals and metabolic substrates to full oocyte maturation. This could result in alterations and deficiencies of patterns of protein synthesis during meiotic progression compromising the subsequent potential capacity of oocytes derived from treated sheep to embryo development [24].

The higher ovulation rate induced by FSH/eCG compared with FSH treatment alone can be related to a more sustained recruitment of small follicles.

Lower embryo recovery obtained by FSH/eCG treatment may be due to the abnormal profile of ovarian hormones that can modify the oviductal and uterine transport of ova and embryos within the genital tract.

It is known that the long half-life of eCG could be responsible of the higher recruitment of follicles. The prolonged action of this hormone and its high LH activity may result in a high number of unovulated follicles that persist during the post-ovulatory period, producing abnormal elevated levels of estradiol $[17,24]$ that can affect the uterine physiological environment.

It is known that sheep as goat and bovine oocytes derived from $<1 \mathrm{~mm}$ follicles are incapable of resuming or completing meiosis during in vitro culture $[7,9,16]$. In vitro evidence suggests that, although appreciable amounts of estradiol are detected in follicles of $>0.5 \mathrm{~mm}$ diameter, small antral follicles respond individually and not identically to gonadotrophins indicating a hierarchical development [31]. In sheep, the ability to progress to meiotic cycle and gain the ability to develop up to the blastocyst stage is achieved progressively as follicle diameter increases $[7,18]$. These negative effects due to eCG can occur before ovulation, as a consequence of an unbalanced hormonal profile during oocyte maturation or later, during early embryonic development as an inadequate capacity to cleave. It is possible that, as observed in heifers by Yaakub et al. [42], also in sheep a higher superovulatory response can produce an inferior quality embryo. Our experience has shown that embryos derived from FSH/eCG treatment, not apparently having an abnormal morphology, have a lower number of cells than those derived from FSH alone.

Several aspects can have an influence on the viability rate after vitrification and warming procedures [for review see 36]. The number of cells per embryo is one factor which affects its tolerance to cryopreservation because the surviving blastomeres after vitrification procedures may be insufficient in number to permit the re-expansion of the blastocoelic cavity and continue the physiological development. A lower survival rate after vitrification has been observed in in vitro produced bovine embryos on day 9 which showed poorer quality as judged by the lower cell number than on day 7 or day 8 , offering support for this hypothesis [30].

Repeated vitrification could be used to test the embryo quality in embryo transfer 
programs. It was showed [19] that twicefrozen mouse embryos retain fully functional capability, as assessed by post-thaw pregnancy rates. A three-fold vitrification test could be an indicator of potential in vivo viability, by the selection of a pool of more viable embryos [22], probably caused by the loss of embryos carrying subtle defects undetected, after morphological evaluation.

\section{CONCLUSION}

These experiments showed that FSH/eCG treatment increases the ovarian response but it also heightens the embryo susceptibility to vitrification procedures. The high resistance to cryopreservation of embryos derived from FSH alone could be a suitable indicator of potential in vivo viability, however, transfer experiments are necessary to assess the viability rates of embryos derived from both superovulatory treatments after vitrification. The production of high quality embryos and cryopreservation can offer interesting scientific and economic opportunities to increase selection intensity and reduce the costs in particular in species with low economic value such as sheep.

\section{ACKNOWLEDGEMENTS}

This study was supported by RAIZ (MiRAAF - Italy).

\section{REFERENCES}

[1] Ali J., Shelton J.N., Successful vitrification of day-6 sheep embryos, J. Reprod. Fertil. 99 (1993) 65-70.

[2] Armstrong D.T., Evans G., Factors influencing success of embryo transfer in sheep and goats, Theriogenology 19 (1983) 31-42.

[3] Armstrong D.T., Recent advances in superovulation of cattle, Theriogenology 39 (1993) 7-24.

[4] Bari F., Khalid M., Haresign W., Murray A., Merrell B., Effect of mating system, flushing procedure, progesterone dose and donor ewe age on the yield and quality of embryos within a moet program in sheep, Theriogenology 53 (2000) 727-742.
[5] Boland M.P., Crosby T.F., Gordon I., Ovarian responses in ewes following horse anterior pituitary extract and progestagen treatment, Anim. Reprod. Sci. 6 (1983) 119-127.

[6] Cognie Y., State of the art in sheep-goat embryotransfer, Theriogenology 51 (1999) 105-116.

[7] Cognie Y., Benoit F., Poulin N., Khatir H., Driancourt M.A., Effect of follicle size and of the Fec Boorola gene on oocyte function in sheep, J. Reprod. Fertil. 112 (1998) 379-386.

[8] Cognie Y., Chupin Y., Saumande J., The effect of modifying the FSH/LH ratio during the superovulatory treatment in ewes, Theriogenology 25 (1986) 148.

[9] Crozet N., Ahmed-Ali M., Dubos M.P., Developmental competence of goat oocytes from follicles of different size categories following maturation, fertilization and culture in vitro, J. Reprod. Fertil. 103 (1995) 293-298.

[10] D’Alessandro A., Martemucci G., Colonna M.A., Cafueri C., Todeda F., Some affects of adding $\mathrm{pLH}$ in defined amounts to purified $\mathrm{pFSH}$ to modify $\mathrm{FSH} / \mathrm{LH}$ ratios during the superovulatory treatment of anoestrus ewes, Anim. Reprod. Sci. 47 (1997) 91-98.

[11] Dattena M., Vespignani S., Branca A.S., Gallus M., Ledda S., Naitana C., Cappai P., Superovulatory response and quality of embryos recovered from anestrus ewes after a single injection of porcine FSH dissolved in polyvinylpyrrolidone, Theriogenology 42 (1994) 235-239.

[12] Driancourt M.A., Fry R.C., Effect of superovulation with $\mathrm{pFSH}$ or eCG on growth and maturation of the ovulatory follicles in sheep, Anim. Reprod. Sci. 27 (1992) 279-292.

[13] Fields R.A., Schulman J.D., Fugger E.F., Survival and development of biopsied frozen and refrozen murine embryos, Proc. 7th World Congress IVF \& Assisted Procreation, 1991, pp. 199-120.

[14] Gordon I., Controlled reproduction in sheep and goats, CAB International, Wallingford, 1997.

[15] Holm P., Callesen H., In vivo versus in vitro produced bovine ova: similarities and differences relevant for practical application, Reprod. Nutr. Dev. 38 (1998) 235-246.

[16] Hyttel P., Fair T., Callesen H., Greve T., Oocyte growth, capacitation and final maturation in cattle, Theriogenology 47 (1997) 23-32.

[17] Jabbour H.N., Evans G., Ovarian and endocrine responses of Merino ewes to treatment with eCG and/or FSH-p, Anim. Reprod. Sci. 26 (1991) 93-106.

[18] Ledda S., Bogliolo L., Leoni G., Naitana S., Follicular size affects the meiotic competence of in vitro matured prepubertal and adult oocytes in sheep, Reprod. Nutr. Dev. 39 (1999) 503-508. 
[19] Leibo S.P., Christian C.R., Malinak L.R., In vitro and in vivo survival of twice frozen mouse embryos, Cryobiology 28 (1991) 534

[20] Loi P., Ptak G., Dattena M., Ledda S., Naitana S., Cappai P., Embryo transfer and related technologies in sheep reproduction, Reprod. Nutr. Dev. 38 (1998) 615-628.

[21] Lopez-Sebastian A., Gonzales de Bulnes A., Santiago Moreno J., Gomez Brumet A., Townsend E.C., Inskeep E.K., Effects of follicular status at treatment on follicular development and ovulation in response to FSH in spanish merino ewes, Theriogenology 52 (1999) 505-514.

[22] Martinez A.G., Matkovic M., Cryopreservation of ovine embryos: slow freezing and vitrification, Theriogenology 49 (1998) 1039-1049.

[23] Mermillod P., Baril G., Beckers J.F., Cognie Y., Successful direct embryo transfer of vitrified sheep embryos., Proc. 14th ICAR, 2000 16:11.

[24] Moor R.M., Osborn J.C., Crosby I.M., Gonadotrophin-induced abnormalities in sheep oocytes after superovulation, J. Reprod Fertil. 74 (1985) 167-172.

[25] Naitana S., Dattena M., Gallus M., Loi P., Branca A., Ledda S., Cappai P., Recipient synchronization affects viability of vitrified ovine blastocyst, Theriogenology 43 (1995) 1371-1378.

[26] Naitana S., Ledda S., Loi P., Leoni G., Bogliolo L., Dattena M., Cappai P., Polyvinyl alcohol as a definite substitute for serum in vitrification and warming solution to cryopreserve ovine embryos at different stage of development, Anim. Reprod. Sci. 48 (1997) 247-256.

[27] Quirke J.F., Hanrahan J.P., Comparison of the survival rates in the uteri of adult ewes of cleaved ova from adult ewes and ewe lambs, J. Reprod. Fertil. 51 (1977) 87-89.

[28] Rubianes E., Ibarra D., Ungerfeld R., Carcaial B., de Castro T., Superovulatory response in anaestrous ewes is affected by the presence of a large follicle, Theriogenology 43 (1995) 465-472.

[29] Ryan J.P., Hunton J.R., Maxwell M.C., Increased production of sheep embryos following superovulation of Merino ewes with a combination of pregnant mare serum gonadotrophin and follicle stimulating hormone, Reprod. Fertil. Dev. 3 (1991) 551-560.

[30] Saha S., Suzuki T., Vitrification of in vitro produced bovine embryos at different ages using one-and three-step addition of cryoprotective additives, Reprod. Fertil. Dev. 9 (1997) 741-746

[31] Scaramuzzi R.J., Adams N.R., Baird D.T., Campbell B.K., Downing J.A., Findlay J.K., Henderson K.M., Martin G.B., McNatty K.P., McNeilly A.S., Tsonis C.G., A model for follicle selection and determination of ovulation rate in the ewe, Reprod. Fertil. Dev. 5 (1993) 459-478.

[32] Tervit H.R., Goold P.G., Deep-freezing of sheep embryos, Theriogenology 21 (1984) 268.

[33] Torres S., Cognie Y., Colas C., Transfer of superovulated embryo obtained with different FSH-p, Theriogenology 27 (1987) 407-419.

[34] Torres S., Sevellec C., Atlas of the early development of sheep embryos INRA publications (1987), Versailles, France.

[35] Trounson A.O., Moore N.W., 1974. Fertilization in the ewe following multiple ovulation and uterine insemination, Aust. J. Biol. Sci. 27 (1974) 505-510.

[36] Vajta G., Vitrification of the oocytes and embryos of domestic animals, Anim. Reprod. Sci. 61 (2000) 357-364.

[37] Van Soom A., Boerjan M.L., Vanroose G., Lein A., Coryn M., de Kruif A., Timing of compactation and inner cell allocation in bovine embryos produced in vivo after superovulation, Biol. Reprod. 57 (1997) 1041-1049.

[38] Vitale N.J., Myers M.W, Denniston R.S., Leibo S.P., Godke R.A., In-vitro development of refrozen mouse embryos, Hum. Reprod. 12 (1997) 310-316.

[39] Walker S.K., Smith D.H., Seamark R.F., Timing of multiple ovulation in the ewe after treatmen with FSH or eCG with or without GnRH, J. Reprod. Fertil. 77 (1986) 135-142.

[40] Whyman D., Moore R.W., Effects of eCG and the PGF2 $\alpha$ analogue, Cloprostenol, on superovulation, fertilization and egg transport in the ewe, J. Reprod. Fertil. 60 (1980) 267-272.

[41] Willadsen S.M., Polge C., Rowson L.E.A., Moor R.M., Deep-freezing of sheep embryos, J. Reprod. Fertil. 46 (1974) 151-154.

[42] Yaakub H., Duffy P., Callaghan D.O., Boland M.P., Effect of timing of oestradiol benzoate injection relative to gonadotrophin treatment on superovulatory response and on yield and quality in beef heifers, Anim. Reprod. Sci. 52 (1998) 191-204.

To access this journal online: www.edpsciences.org 